\title{
KAPASITAS TAMPUNG HIJAUAN PAKAN DALAM AREAL PERKEBUNAN KOPI DAN PADANG RUMPUT ALAM DI KABUPATEN FLORES TIMUR NUSA TENGGARA TIMUR
}

\author{
Markus M. Kleden*, M. R. D. Ratu*, dan M.D.S. Randu**
}

\begin{abstract}
ABSTRAK
Penelitian ini dilakukan di area pertanaman kopi dan lahan pasture dengan tujuan untuk mengetahui produksi dan lkualitas pakan ternak. Penelitian dilakukan dengan metode survey. Data primer diperoleh dari Kecamatan Wulanggitang Kabupaten Flores timur khususnya di perkebunan kopi dan area pastura. Data primer berupa produksi dan kualitas rumput termasuk kesuburan tanah secara fisika kimia pada area perkebunan kopi. Data sekunder diperoleh dari instansi terkait menyangkut iklim dan topografi wilayah. Hasil peneloitian menunjukkan bahwa potensi pakan di Kecamatan Wulanggitang mencapai 7,664 ton/ha bzhan segar di area perkebunan kopi dan 6,98 ton/ha rumput segar di area pastura secara berturut turut. Hasil ini mengindikasikan bahwa area perkebunan kopi dapat menampung 0,42 unit ternak dan 0,38 unit ternak di areal pasture. Topografi Kecamatan Wulanggitang berkisar antara 0\% - $>40 \%$. Komposisi kimia rumput pakan adalah $6,95 \%$ protein kasar di areal perkebunan kopi dan $6,65 \%$ di area pasture. Hal ini menunjukkan bahwa ketersediaan protein kasar di area penelitian sudah melebihi kebutuhan minimum ternak. Kesimpulannya adalah potensi sumber daya pakan dia kedua area penelitian tidak mendukung perkembangan ternak khususnya ternak sapi di Kecamatan Wulanggitang padahal sumber pakan hijauan ternak hanya bersumber dari kedua area tersebut.
\end{abstract}

Kata kunci :kualitas hijauan pakan, perkebunan kopi, pasture alami, daya tampung

*Fakultas Peternakan UNDANA Kupang

***Politeknik Negeri Kupang
ABSTRACT

CARRYING CAPACITY OF FORAGE IN COFFEE FARM AND NATIVE PASTURE AREA AT DISTRICT OF FLORES TIMUR, EAST NUSA TENGGARA. Research was conducted at coffee farm and native pasture area with the objective to measure the production and quality of forage. The research method used was survey method. Primary data were collected at Sub-district of Wulanggitang - District of Flores Timur, particularly in the coffee farm and the native pasture areas. Primary data consisted of production and quality of the native grasses including land fertility -both physical and chemical - in the coffee farm area. On the other hand, secondary data were taken from related institutions cover climate condition and topography. The result showed that potency of forage resources in the Sub-District of Wulanggitang reach 7,664 ton fresh matter/ha for the coffee farm and 6.98 ton fresh matter/ha for the native grasses, respectively. The total production may figure carrying capacity of the coffee farm area is $0.42 \mathrm{UT} / \mathrm{ha}$ and $0.38 \mathrm{ST} / \mathrm{ha}$ of the native grasses, respectively. In addition, the topography of Wulanggitang Sub-district was about $0 \%->$ $40 \%$. Moreover, chemical composition of the forages, mainly crude protein, was $6.95 \%$ in the coffee farm area and $6.65 \%$ in the native pasture area, respectively. It was found that the forages crude protein was very high and available over the livestock minimum needed. Composition of the crude protein was high since the forages are relatively young due to high rainy distribution in a few weeks before taking the sample. However, although the crude composition of the forages in the coffee farm - both quantitatively and qualitativelywas higher than that of the native pasture, its function to support the feed resources was not significant. In conclusion, the potency of the forage resources in those two areas was not 
support the livestock development especially beef cattle farm at the Sub-district of Wulanggitang when it depends only on the forages of these two areas.

Key words: Forage quality, Stocking rate, Coffee farm, Native pasture, Carrying capacity

\section{PENDAHULUAN}

Pembangunan yang berdasarkan pada kemampuan yang dimiliki oleh masyarakat merupakan salah satu kebijakan yang tepat. Kebijakan ini mengisaratkan bahwa semua kemampuan yang ada pada masyarakat perlu digali, dikembangkan dan didayagunakan secara maksimal yang berorientasi pada peningkatan pendapatan dan kesejahteraan masyarakat.

\section{Pelaksanaan}

pembangunan

pertanian yang berbasiskan peternakan terutama peternakan sapi potong akan dapat dilaksanakan secara optimal jika diketahui secara pasti faktor-faktor pendukung yang berpengaruh terhadap usaha tersebut. Semua faktor pendukung yang ada tidak berpengaruh secara individu tetapi akan saling berinteraksi, oleh karenanya semua faktor pendukung yang ada perlu dipelajari secara lebih mendalam sehingga dapat diambil kebijakan yang tepat dalam penentuan pengembangan suatu komoditas berdasarkan potensi wilayah yang ada.
Fakta memperlihatkan bahwa jumlah curah hujan tahunan di propinsi Nusa Tenggara Timur relatif rendah dan berlangsung dalam jangka waktu yang singkat. Kenyataan ini telah membawa dampak pada pembangunan sektor pertanian yang berbasiskan peternakan menjadi salah satu sektor unggulan. Dalam kaitan dengan hal tersebut maka semua faktor yang mempengaruhi ketersediaan hijauan pakan dan faktor pendukung lainnya perlu digali dan dikembangkan guna menjaga kesinambungan usaha.

Produksi dan kualitas hijaun pakan terutama rumput alam yang tersebar dalam areal perkebunan kopi yang tumbuh dan berkembang di bawah naungan tanaman kopi serta hamparan padang penggembalaan umumnya sangat tergantung pada interaksi antara faktor genetik dengan faktor lingkungan. Penurunan kualitas hijauan pakan berfluktuasi mengikuti perubahan musim. Konsekuensinya ketersediaan hijauan baik jumlah maupun kualitas menjadi sangat terbatas dan sekaligus menjadi faktor pembatas pengembangan ternak selama musim kemarau.

Semua hijauan yang dapat dimakan ternak baik yang tumbuh dan berkembang di sisi kiri-kanan jalan, areal kebun/lading, areal perkebunan serta areal padang rumput alam merupakan potensi yang 
perlu digali keberadaannya sehingga menjadi asset dalam pengembangan usaha ternak ruminansia khususnya ternak sapi potong. Pengembangan ternak sapi potong tidak bisa terlepas dari upaya penyediaan hijauan makanan ternak secara berkelajutan. Dalam kaitan dengan hal tersebut maka semua aspek yang mempengaruhi penyediaan pakan harus digali dan dikembangkan guna memperoleh produksi ternak yang optimal. Untuk itu dapat dituangkan dalam bentuk pemanfaatan semua potensi yang ada di masyarakat sebagai basis utama pembangunan.

Kleden (2001) melaporkan bahwa produksi rumput alam yang tersebar dalam hamparan padang penggembalaan di Kabupaten Lembata sebesar 1065 kg/ha dengan kandungan protein kasar sebesar $4,23 \%$. Dari produksi yang ada memiliki kapasitas tampung sebesar 0,66 ST/ha/tahun. Dari segi kualitas, kandungan protein yang ada berada jauh dibawah ambang kebutuhan minimal bagi ternak sehingga secara umum selalu terjadi penurunan berat badan ternak sebesar 30$60 \mathrm{~kg}$ selama musim kemarau (Bamualim dan Momuat, 1993). Penurunan berat badan ternak yang terjadi selain dipengaruhi oleh ketersediaan jumlah dan kaulitas pakan yang terbatas, juga dipengaruhi oleh faktor penggembalaan berlebih (over grassing).

Sedangkan kualitas rumput alam di di Nusa Tenggara Timur khususnya di pulau Timor termasuk dalam kategori yang rendah yang ditandai oleh rendahnya kandungan protein kasar yaitu sebesar 5,8 $\%$ selama musim hujan dan 3,8\% selama musim kemarau (Arsyad, 1988). Kandungan dinding sel sebesar $65 \%$ selama musim hujan dan meningkat menjadi $85 \%$ selama musim kemarau (Bamualim, 1988). Rendahnya kualitas pakan yang ada karena sebagian besar wilayah NTT termasuk dalam kategori lahan kering. Penurunan kualitas hijauan pakan disebabkan karena kekurangan air yang mengakibatkan hasil fotosintesis menjadi semakin berkurang sedangkan proses respirasi tetap berlangsung konsekuensinya sebagian besar metabolit terlarut akan hilang yang mengakibatkan rasio dinding sel dan isi sel menjadi semakin besar sehingga kandungan dinding sel meningkat selama musim kemarau.

Kecamatan Wulangitang merupakan salah satu kecamatan yang terdapat di Kabupaten Flores Timur. Selain memiliki areal padang penggembalaan, wilayah ini juga memiliki areal perkebunan kopi yang cukup luas. Dari habitat tanaman kopi sebenarnya ada 
potensi hijauan pakan yang dapat dimanfatkan sebagai sumber pakan bagi ternak ruminansia khususnya ternak sapi yang pemanfaatannya dapat dilakukan dengan cara sistim ikat pindah, digembalakan secara bebas maupun dengan cara potong angkut. Seberapa besar potensi sumberdaya pakan baik jumlah maupun kualitasnya serta tingkat pemanfaatan hijauan pakan ternak dalam areal perkebunan kopi belum banyak diketahui.

Selain memiliki areal perkebunan kopi, wilayah Kecamatan Wulangitang juga mempunyai areal padang rumput alam yang cukup luas. Meskipun demikian, potensi produksi dan kualitas hijauan rumput alam sebagai sumber pakan bagi ternak belum banyak diketahui, sehingga telaahan ini merupakan sumber informasi penting dalam rangka pemnafaatan semua potensi sumberdaya yang tersedia.

Secara klimatik, kondisi iklim di Kecamatan Wulanggitang Kabupaten Flores Timur memiliki kondisi iklim yang relatif kering. Kendala utama yang terjadi di lahan kering adalah keterbatasan air yang menjamin pertumbuhan tanaman. Ketersediaan air pada lahan kering sangat tergantung pada curah hujan yang jumlahnya sangat terbatas dan tidak teratur sepanjang tahun yang mengakibatkan cekaman kekeringan (Tohari, dkk. 1996).

Mencermati akan hal tersebut maka areal perkebunan kopi dan padang rumput alam sebagai penyedia pakan bagi pengembangan ternak sapi yang paling murah dan mudah pemanfaatannya perlu digali potensinya sehingga dapat dijadikan sebagai acuan dalam usaha pengembangan ternak sapi. Pendekatan tersebut dapat dituangkan dalam bentuk kegiatan penelitian sehingga diketahui secara pasti daya dukung sumberdaya pakan secara umum yang dapat digunakan sebagai acuan bagi pengembangan pembangunan peternakan di masa mendatang.

\section{MATERI DAN METODE PENELITIAN}

\section{Lokasi dan Waktu Penelitian}

Penelitian ini akan dilaksanakan di Kecamatan Wulan Gitang Kabupaten Flores Timur. Metode yang digunakan adalah metode survey serta pengukuran dan pengamatan langsung di lapangan. Hamparan padang rumput alam yang biasa digunakan peternak diambil sebagai sampel. Disamping itu, pengukuran dan pengamatan juga dilakukan di areal perkebunan kopi yang dikelola masyarakat. Pengambilan data populasi ternak dari dinas dan instansi terkait. 


\section{Data dan sumber data}

Data yang diambil dalam penelitian ini adalah data primer dan data sekunder. Data primer diperoleh dari pengukuran dan pengamatan langsung di lapangan yang meliputi jumlah produksi dan kualitas hijauan pakan (rumput alam dan leguminosa) serta kesuburan tanah. Data sekunder bersumber dari literatur dan dinas/instansi terkit yang meliputi kondisi geografis, jumlah curah hujan per tahun , distribusi jumlah curah hujan bulanan selama setahun serta rata-rata temperatur harian selama 5 tahun terakhir.

\section{Cara pengukuran data}

Metode yang digunakan dalam penelitian adalah metode survey serta pengamatan dan pengukuran langsung di lapangan.

Pengukuran produksi hijauan dilakukan dengan metode Halls dalam Susetyo (1980) yaitu dengan menggunakan metode bingkai kuadrat $1 \mathrm{~m}$ x 1m. Penempatan bingkai kuadrat dilakukan dengan menggunakan bilangan teracak. Sebanyak 50 titik pengamatan untuk satu hamparan padang rumput alam yang ada. Semua hijauan yang ada dalam bingkai kuadrat dipotong dan ditimbang untuk mengetahui produksi bahan segar. Pengambilan sampel untuk dianalisis di labotratorium dengan tujuan untuk mengetahui kandungan gizi dilakukan dengan cara komposit yaitu mencampur semua hijauan yang telah dipotong dan diambil $\pm 1 \mathrm{~kg}$. Analisis kandungan gizi rumput alam dilakukan di laboratorium Nutrisi dan Makanan Fakultas Petrnakan Universitas Nusa Cendana.

Pengambilan sampel tanah dilakukan secara komposit pada kedalaman $\quad 0-20 \quad \mathrm{~cm} . \quad$ Titik-titik pengambilan sampel tanah dilakukan dengan cara membuat garis diagonal dan ditentukan 3-4 titik pengambilan sampel tanah untuk dianalisis kesuburan kimia $(\mathrm{N}, \mathrm{P}, \mathrm{K})$ dan kesuburan fisik (tekstur, struktur dan $\mathrm{pH}$ ). Analisis kesuburan tanah dilakukan di laboratorium tanah Fakultas Pertanian Universitas Nusa Cendana.

\section{Peubah yang diukur dan diamati}

Peubah yang diukur dan diamati dalam penelitian ini adalah:

1. Produksi hijauan yang ada. Pengukuran produksi hijauan dilakukan dengan menggunakan metode Halls dalam Susetyo (1980) yaitu menggunakan bingkai kuadrat $1 \mathrm{~m} \times 1 \mathrm{~m}$ secara dsetruksi sampling (Sutaryo, 2009). Sebanyak 50 titik pengamatan dalam suatu hamparan padang rumput yang sering dimanfaatkan masyarakat petani/peternak. Penempatan bingkai kuadrat untuk 
masing-masing titik pengamatan berdasarkan bilangan teracak. Rata-rata produksi hijauan dihitung dengan menggunakan rumus:

$$
X=\text {--------------------- }
$$

Dimana: $\mathrm{X}=$ rata-rata produksi biomassa hijauan yang ada

$\sum x i=$ jumlah produksi biomassa hijauan pada setiap pengamatan

$\mathrm{n} \quad=$ Jumlah pengamatan

2. Kualitas hijauan yang ada. Diukur dengan cara mengambil sampel hijauan yang ada secara acak ntuk masing-masing titik pengamatan, dikomposit dan dianalisis dengan menggunakan analisis proximat untuk mengetahui kandungan BK, protein kasar, serat kasar, BETN, bahan oragink, abu, NDF dan ADF.

3. Kapasitas tampung. Penentuan besarnya kapasitas tampung dilakukan melalui pendugaan konsumsi bahan kering/Satuan Ternak (ST)/hari yaitu sebesar 1,4 - $3 \%$ berat badan dan besarnya produksi hijauan yang ada setelah dilakukan pengukuran.

\section{Analisis data}

Semua data primer yang ada akan ditabulasi untuk mendapatkan nilai ratarata dan persentasenya. Kualitas hijauan yang terdapat dalam hamparan padang rumput alam dilokasi penelitian diperoleh dengan menggunaka analisis proximat kemudian dideskripsi tentang kualitas secara umum. Data menyangkut kapasitas tampung padang rumput alam diperoleh diperoleh melalui total kebutuhan ternak dengan mengacu pada total produksi hijauan dan limbah pertanian yang ada. Data kapasitas tampung akan dianalisis dengan membandingkan produksi hijauan dengan jumlah ternak yang tersedia untuk mengetahui rasio keduanya yang menggambarkan jumlah ternak sapi potong yang bisa dikembangka di wilayah penelitian dengan menggunakan formulasi sebagai berikut:

a. STm/STt $<1$ : jika terdapat jumlah ternak yang digembalakan padang rumput alam yang ada melebihi jumlah makanan ternak yang tersedia. Pada kondisi ini perlu ada pengurangan jumlah ternak untuk menjaga agar laju degradasi lahan tidak terjadi.

b. $\mathrm{STm} / \mathrm{STt}=1$ : Jika terdapat keseimbangan antara jumlah makana ternak yang tersedia dengan jumlah ternak yang digembalakan di atasnya. Pada kondisi ini pengembangan ternak dalam sistem penggemukan perlu 
dilakukan untuk meningkatkan produksi ternak yang ada.

c. STm/STt $>1$ : Jika jumlah ternak yang digembalakan pada hamparan padang rumput alam yang ada kurang dari jumlah makanan ternak yang tersedia dalam hamparan padang rumput tersebut. Pada kondisi ini penambahan jumlah ternak untuk dikembangkan masih sangat mungkin dilakukan guna meningkatkan produksi ternak dan tingkat pendapatan masyarakat.

Keterangan: STm dan STt masing-masing adalah satuan ternak untuk makanan dan satuan ternak untuk ternak.

\section{HASIL DAN PEMBAHASAN}

\section{Lokasi Penelitian}

Penelitian ini telah dilaksanakan di Kecamatan Wulanggitang Kabupaten Flores Timur.

\section{Letak Geografis}

Kecamatan Wulanggitang merupakan salah satu Kecamatan yang terletak di Kabupaten Flores Timur. Memiliki letak geografis adalah sebagai berikut sebelah Utara berbatasan dengan Kecamatan Titehena; Selatan dengan laut Sawu; Timur berbatasan dengan selat Lewotobi dan Barat berbatasan dengan Kabupaten Sikka. Total luas wilayah Kecamatan Wulanggitang adalah sebesar
223,99 km2 dan tersebar dalam berbagai kondisi kemiringan lereng dari datar hingga berombak dan bergelombang (Anonimous, 2010).

\section{Potensi Sumberdaya Pakan}

Sumberdaya pakan yang terdapat dalam suaru areal atau wilayah dapat berupa areal padang rumput alam, areal kebun hijauan makanan ternak maupun ketersediaan sumberdaya limbah pertanian. Hasil pengamatan yang dilakukan di wilayah padang rumput alam dan dalam areal perkebunan kopi menunjukkan bahwa produksi rumput alam yang ada cukup tinggi. Tingginya produksi yang ada karena adanya curah hujan yang terjadi sebelumnya. Meskipun masalah umum yang terjadi di daerah tropis adalah terbatasnya sumber air, namun respon tanaman terhadap ketersediaan air cukup tinggi. Rumput alam akan segera bertunas dan menghasilkan hijauan bila terjadi hujan.

Hijauan yang terdapat di areal padang rumput alam dan areal perkebunan kopi di Kecamatan Wulanggitang Kabupaten Flores Timur didominasi oleh rumput lokal dengan memiliki produksi bahan segar rata-rata sebesar 766,4 gram/m2 untuk areal perkebunan kopi atau setara dengan 7,664 ton/ha. Untuk areal padang rumput menghasilkan produksi bahan segar sebesar 698 gram/m2 atau 
setara dengan 6,98 ton/ha. Meskipun produksinya cukup tinggi, namun areal ini sudah mulai ditumbuhi oleh cromolaena odorata. Invasi tanaman ini sangat cepat penyebarannya sehingga dikuatirkan bahwa pada suatu saat areal padang penggembalaan didominasi oleh cromolaena odorata sehingga akan menurunkan produksi rumput alam.

Data menyangkut produksi dan kualitas rumput alam di areal padang rumput alam di Kecamatan Wulanggitang seperti tertera dalam Tabel 1.

\section{Tabel 1. Produksi dan Kualitas Rumput Alam di Areal Kebun Kopi dan} Padang Rumput Kecamatan Wulanggitang Kabupaten Flores Timur

\begin{tabular}{|l|l|l|}
\hline \multirow{2}{*}{ Item } & \multicolumn{2}{|c|}{ Jumlah } \\
\cline { 2 - 3 } & Areal Kebun Kopi & Areal Padang Rumput \\
\hline Produksi Bahan Segar (ton/ha) & 7,664 & 6,98 \\
Satuan Ternak untuk Makanan (STm) & 21.42 & 308,65 \\
Satuan Ternak untuk Ternak (STt) & $1.261,8$ & $1.261,8$ \\
Kapasitas Tampung (ST/Ha/Thn) & 0,42 & 0,38 \\
STm/STt & 0,02 & 0,24 \\
& & \\
Komposisi Kimia: & & \\
Bahan Kering (\%) & 30,19 & 32,73 \\
Protein Kasar (\%) & 6,95 & 6,65 \\
Lemak Kasar (\%) & 1,35 & 1,23 \\
BETN (\%) & 50,16 & 53,35 \\
Serat Kasar (\%) & 34,57 & 35,59 \\
NDF (\%) & 72,37 & 74,89 \\
ADF (\%) & 55,15 & 57,22 \\
Abu (\%) & 8,11 & 8,22 \\
Energi (kkal/kg) & 3856 & 3823 \\
\hline
\end{tabular}

Tingginya produksi hijauan dalam areal kebun kopi karena keadaan tanah disekitarnya relatife lembab yang memungkinkan hijauan rumput dapat bertumbuh dan menghasilkan hijauan sebagai sumber pakan. Tingginya kelembaban karena adanya canopy tanaman kopi dan canopy dari tanaman pelindung tanaman kopi yang menyebabkan evaporasi tanah rendah.
Meskipun produksi per hektarnya lebih tinggi, namun karena total luasan areal kebun kopi relatif terbatas sehingga memiliki total satuan ternak untuk makanan relatif lebih rendah dibandingkan dengan areal padang rumput alam.

Total hijauan per hektar untuk areal padang rumput alam sebesar 6,98 ton dengan total satuan ternak untuk makanan sebesar 308,65. Angka yang diperoleh 
akan semakin besar apabila jumlah curah hujan berlangsung secara merata sepanjang tahun terutama saat puncak musim hujan (bulan Januari hingga Maret).

Jika dibandingkan rasio antara ketersediaan hijauan makanan ternak dan jumlah ternak yang tersedia, maka angka perbandingan yang ada $<1$. Hal ini mengindikasikan bahwa usaha pengembangan ternak sapi potong di wilayah Kecamatan Wulanggitang Kabupaten Flores Timur tidak dapat lagi dilakukan. Jumlah ternak yang ada perlu dikurangi sehingga terjadi keseimbangan antara jumlah ternak dengan jumlah pakan yang tersedia.

Secara kualitatif hijauan yang dihasilkan baik dalam areal kebun kopi maupun dalam areal padang rumput sangat baik. Kualitas yang ditentukan oleh indikator kandungan protein kasar tinggi yaitu sebesar 6,95\% dan 6,65\% masingmasing untuk areal kebun kopi dan padang rumput alam. Kandungan protein yang ada melebihi kebutuhan minimal ternak ruminansia. Tingginya kandungan protein yang ada karena hijaun rumput yang tersebar dalam areal kebun kopi dan padang rumput alam merupakan hijauan yang baru bertumbuh dan relative muda akibat adanya curah hujan yang terjadi beberapa bulan sebelumnya. Fakta ini menunjukan bahwa produksi dan kualitas hijauan rumput alam di daerah tropis sangat ditentukan oleh ketersediaan air tanah yang menunjang proses fisiologis tanaman.

Walaupun kandungan protein hijauan rumput alam cukup tinggi namun secara kuantitatif jumlahnya sangat rendah sehingga kurang menjamin pertumbuhan dan produktifitas ternak ruminansia. Hal ini dapat dilihat dari rasio antara satuan ternak untuk makanan dan satuan ternak untuk ternak (STm/STt). Secara umum terlihat bahwa rasio antara STm dan STt mempunyai nilai kurang dari 1. Angka ini menggambarkan bahwa pengembangan ternak ruminansia termasuk didalamnya ternak sapi sudah sangat tidak dimungkinkan untuk dilakukan. Populasi yang adapun harus dikurangi karena jumlah hijuan yang tersedia tidak memenuhi kebutuhan ternak jika hanya mengandalkan hijauan pakan yang berasal dari areal kebun kopi maupun areal padang rumput alam.

Jika dikaitkan dengan pemanfaatan areal yang ada di Kecamatan Wulanggitang sebagian besar digunakan untuk kebun/tegalan, maka tersedia cukp banyak hijauan limbah pertanian. Produk inilah yang perlu dikelola dan dimanfaatkan sebagai sumber pakan bagi ternak sehingga secara kuantitaif dan 
kualitatif dapat memenuhi kebutuhan ternak dan dapat menunjang pengembangan usaha ternak ruminansia yang ada. Disamping itu produksi dari hijauan pakan ternak yang tersedia dalam areal perkebunan juga merupakan salah satu sumber pakan bagi ternak ruminansia. Hal ini perlu dikaji dan dikelola sehingga pengembangan usaha ternak sapi potong dapat dilaksanakan dengan memanfaatkan semua sumberdaya pakan yang tersedia.

\section{KESIMPULAN}

Dari penelitian ini dapat disimpulkan:

1. Potensi sumberdaya pakan yang terdapat di wilayah Kecamatan Wulan Gitrang Kabupaten Flores Timur memiliki kapasitas tampung sebesar $0,42 \mathrm{ST} / \mathrm{ha} /$ thn untuk areal kebun kopi dan 0,38 ST/ha/thn untuk areal padang rumput

2. Kandungan protein kasar sebagai indikator kualitas hijauan pakan pada areal perkebunan kopi dan padang rumput masing-masing sebesar $6,95 \%$ dan $6,65 \%$.

3. Perbandingan antara jumlah hijauan pakan yang tersedia dan jumlah ternak yang ada sebesar $<1$ yang mengindikasikan bahwa pengembangan ternak sapi potong tidak dapt dilakukan dengan hanya mengandalkan hijauan yang tersedia baik dari areal kebun kopi maupun areal padang rumput.

4. Pemanfaatan sumberdaya pakan lainnya seperti limbah pertanian dan hasil ikutan dari areal perkebunan dan hutan merupakan terobosan yang perlu dikembangkan guna memenuhi kecukupan pakan bagi ternak

\section{DAFTAR PUSTAKA}

Anonymous, 1980. Usaha Peternakan, Perencanaan Usaha, Analisa, dan Pengelolaan. Direktorat Bina Usaha Petani Ternak dan Pengelolaan Hasil Peternakan.

--, 1992. Rencana Umum Tata Ruang Daerah Kabupaten Dati II Flores Timur. Rencana 1992. Pemerintah Kabupaten Dati II Flores Timur Bekerjasam dengan PT Multicipta Rencana Selaras Consultant.

--, 2002. Flores Timur Dalam Angka. BPS Kabupaten Dati II Flores Timur.

$\begin{array}{llr} & & \\ \text { Pertanian } & \text { Balai } & \text { Penyuluhan } \\ \text { Pertanian } & \text { Boru } & \text { Kecamatan } \\ \text { Wulanggitang. } & \end{array}$

Arsyad, K.M., 1988. Pengaruh Tekanan Penggembalaan Terhadap Produksi dan Komposisi Botani Padang Rumput Alam dan Hubungannya Pertumbuhan Domba. Laporan Penelitian Fakultas Peternakan Universitas Nusa Cendana Kupang. 
Bamualim A. dan E.O. Momuat., 1993. Sistem Produksi Hijauan Legum di Indonesia Bagian Timur. Kasus Nusa Tenggara Timur. Forum Komunikasi Hasil Penelitian Bidang Peternakan. Kumpulan Makalah Kelompok A/I Sub Bidang Pakan dan Nutrisi Ternak. Departemen Pendidikan dan Kebudayaan. Dirjen Pendidikan Tinggi. Direktorat Pembinaan Penelitian dan engabdian Pada Masyarakat.

Dwiyanto, K. dan Bambang R. Prawiradaputra., 1995. Keunggulan Komparatif Lahan Kering sebagai Wilayah Pengembangan Peternakan. Makalah yang Disampaikan dalam: Seminar Komunikasi dan Aplikasi Hasil Penelitian Peternakan Lahan Kering. Depertemen Pertanian. Badan Penelitian dan Pengembangan Pertanian Sub Penelitian Ternak Kupang.

Kleden, M.M., 2001. Produksi Rumput Alam Dalam Mendukung Pengembangan Sapi Potong di Kecamatan Lebatukan, Kabupaten Lembata. Jurnal Informasi Pertanian Lahan Kering. Pusat Penelitian Lahan Kering Lembaga Penelitian Universitas Nusa Cendana Kupang. No. 8 Januari 2001.

Reksohadiprodjo, S. 1981. Produksi Tanaman Hijauan Makanan Ternak Tropik. Bagian Penerbitan Fakultas Ekonomi Universitas Gadjah Mada. Yogyakarta.

Salean E. Th., 1995. Rencana Pengembangan Peternakan Rakyat di Nusa Tenggara Timur. Makalah yang disampaikan dalam seminar: Seminar Komunikasi dan Aplikasi Hasil Penelitian Peternakan Lahan
Kering. Departemen Pertanian. Badan Penelitian dan Pengembangan Pertanian. Sub Balai Penelitian Ternak. Kupang.

Seta, A.K., 1987. Konservasi Sumberdaya Tanah dan Air. Kalam Mulia Jakarta.

Sutaryo, D., 2009. Perhitungan Biomassa. Sebuah Pengantar untuk Studi Karbon dan Perdagangan Karbon. Wetlands International Indonesia Programme.

Suradisastra, K. 1980. Tekanan Penggembalaan. Media Peternakan dan Industri Peternakan. Ranch No. 5 Januari 1980.

Susetyo, S., 1980 Padang Penggembalaan. Balai Latihan Pegawai Pertanian Batangkaluku. Badan Pendidikan Latihan dan Penyuluhan Pertanian. Departemen Pertanian.

Taleni, E., R.S.F. Champbell and D. Haffman., 1993. Draught Animal Systems and Managemant: An Indonesian Study. ACIAR.

Tohari., Pudji Lestari dan Djoko Muljanto., 1996. Kajian Adaptasi Kultivar Gude (Cajanus cajan $(L)$ Millsp.) Terhadap Kekeringan. Berkala Penelitian Pasca Sarjana. Universitas Gadjah Mada. Yogyakarta. Jilid 9 Nomor 1B Februari 1996.

Van Soest. P.J., 1994. Nutritional Ecology of The Ruminant. Second Edition. Comstock Publishing Asosiates Cornell University Press. Ithaca and London.

Whiteman, P.C., 1980. Tropical Pasture Science. Oxford University Press. 
